\title{
Erratum: Doing theology with children: A childist reading of the childhood metaphor in 1 Corinthians and the Synoptic Gospels
}

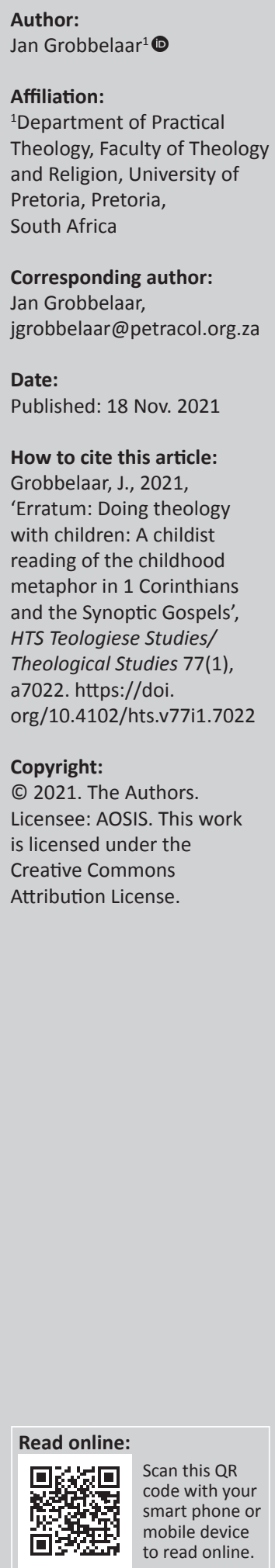

In the initially published version of this article, Grobbelaar, J., 2020, 'Doing theology with children: A childist reading of the childhood metaphor in 1 Corinthians and the Synoptic Gospels', HTS Teologiese Studies/Theological Studies 76(4), a5637. https:/ /doi.org/10.4102/hts.v76i4.5637, on page 8, the 'Ethical consideration' statement was incorrectly written as: 'This was a research project using human subjects in a low-risk informal survey. The participants were informed of the purpose of the research and participated voluntarily and anonymously'. The correct ethical clearance statement is updated as follows: 'This article followed all ethical standards for a research without direct contact with human or animal subjects'.

This correction does not alter the significance of the study's findings or the overall interpretation of the study results. The publisher apologises for any inconvenience caused. 


\section{Doing theology with children: A childist reading of the childhood metaphor in 1 Corinthians and the Synoptic Gospels}

\begin{abstract}
Author:
Jan Grobbelaar ${ }^{1}$ (1)

Affiliation

${ }^{1}$ Department of Practical

Theology, Faculty of Theology and Religion, University of

Pretoria, Pretoria,

South Africa

Research Project Registration: Project Leader: S.F. de Beer Project Number: 86233689

\section{Description:}

This research is part of the research project, 'Children, Faith and Society', directed by Prof Stephan de Beer, director of the Centre for Contextual Ministry and associate professor in the Department of Practical Theology, Faculty of Theology and Religion, University of Pretoria.
\end{abstract}

Corresponding author: Jan Grobbelaar,

jgrobbelaar@petracol.org.za

Dates:

Received: 02 July 2019

Accepted: 24 Apr. 2020

Published: 19 Aug. 2020

How to cite this article: Grobbelaar, J., 2020, 'Doing theology with children: A childist reading of the childhood metaphor in 1 Corinthians and the Synoptic Gospels', HTS Teologiese Studies/Theological Studies 76(4), a5637. https://doi. org/10.4102/hts.v76i4.5637

\section{Copyright:}

C2020. The Authors. Licensee: AOSIS. This work is licensed under the Creative Commons Attribution License.

Read online:

Scan this $Q R$ code with your smart phone or mobile device to read online.
This article is written from the perspective of Child Theology and a childist reading of scripture. Firstly, the article deals with the links between children, childhood and Childhood Studies, as well as with Theology. Secondly, in terms of a childist reading of scripture, it explains the difference between a low and a high view of childhood. The fact that both views of childhood are present in the Bible is highlighted. Thirdly, the article discusses three texts in 1 Corinthians, where Paul used the childhood metaphor in a way that reflects a low view of childhood. Then, it investigates passages from the Synoptic Gospels as examples of Jesus' implied high view of childhood. Finally, the article concludes with a challenge addressed to all adult theologians.

Contribution: This article contributes to the enhancement of emancipatory methodologies for doing theology and research with children by exploring the different ways in which the childhood metaphor is used in 1 Corinthians and the Synoptic Gospels through a childist reading of the relevant texts. Through this hermeneutical approach, which places the article clearly in the scope of this Theological Journal, it is established that doing theology with children in an emancipatory way adult theologians have to operate with a high view of childhood, as expressed in the way the childhood metaphor is used in the Synoptic Gospels.

Keywords: 1 Corinthians; child; children; child theology; theology of childhood; childhood metaphor; immaturity; spiritual gifts; speak in tongues; prophecy.

\section{Children and childhood studies}

Since the Convention on the Rights of the Child (CRC) was adopted in 1989, awareness, interest and concern for children have grown globally, stimulated by the work of children's rights organisations and other child-focused organisations like the United Nations International Children's Fund (UNICEF). Over the past 30 years, the CRC has introduced and enhanced a broadening understanding of childhood (cf. https://www.unicef.org/child-rights-convention/ frequently-asked-questions).

In addition to regarding children as objects to be protected by society, children have also come to be valued as subjects of their own lives with full rights. Children are agents, befitting their age and development.

This child-oriented movement has also contributed to a growing focus on studies about children in the academic world, leading to research projects in numerous disciplines that culminated in several child-focussed publications (cf. Grobbelaar 2016a). In these research projects, children have been increasingly involved as co-producers of knowledge. Eventually, Childhood Studies was recognised as a new academic discipline. The complexity of understanding childhood requires a multi- and interdisciplinary research approach (James \& James 2012:19), in which theology has begun to participate.

\section{Children and theology}

Until theologians became involved in Childhood Studies, children and childhood apparently did not get much attention in theological research and thinking. As a result, theologians did not contribute much to this field (cf. Bunge 2004:43, 2006:551, 2012:4; eds. Bunge, Fretheim \& Gaventa 2008:xv; DeVries 2001:162; Miller-McLemore 2003:xxii; Nye 2009:Loc. 1663-1669). Nye (2009:Loc 1663) dubbed this phenomenon as '[c]hildhood and "theological attention deficit"'.

Led by academics such as Bunge (ed. 2001), Berryman (2009), Jensen (2005), Koepf Taylor (2013), Mercer (2005), Miller-McLemore (2003) and Willmer and White (2013), this situation has started to 
change. More and more theological studies on children are being published in which children and theology are related to each other in different ways, leading to different outputs (Grobbelaar 2016b:70-75; Willmer \& White 2013:13-15).

Some scholars have focused on creating a theological understanding of childhood, referred to as "Theologies of Childhood' (cf. Bunge 2016:92-112). Others have used children as their hermeneutical lens to explore God and God's actions in order to gain new insights about God and God's kingdom (Grobbelaar 2016b:72). This has become known as 'child theology'.

Recently, biblical scholars have begun to place intentional focus on children and childhood in reading the Bible, using the term 'Childist Theology' (Parker 2019; cf. eds. Betsworth \& Parker 2019:2-3; Elkins \& Parker 2016:422-433; Garroway 2018:1-6). They have deliberately chosen childhood as their point of departure and read scripture from the perspective of children. 'At its core, childist theory addresses issues raised by its elder hermeneutic: feminist theory. Like feminist theory, it seeks to assign a voice to the silent other' (Garroway 2018:3). Childist theologians read the biblical texts in a childcentred way to give voice to the silent children of this world.

A crucial factor in a childist reading of the Bible, as well as in doing child theology, is your theology of childhood. The critical question is 'how do I view children?' in other words, 'how do I see children, my hermeneutical lenses, through whom I read the Bible?'

\section{A high and a low view of childhood}

Berryman (2009) grouped the different theological views of childhood into two main categories: a high and a low view. He (Berryman 2009:204) stated that the high view 'is respectful to, moves toward, and is open to learning from children'. It emphasises the role of children as social actors or agents, similar to the views expressed in the CRC. A low view, according to Berryman (2009:204), 'is dismissing of, moves away from, and only sees children in a narrow, closed way, as objects to be taught and purified'. Such a view comes to the fore in ambivalence, ambiguity and indifference towards children (Berryman 2009:203-213). Both these views of childhood are present in the Bible.

\section{A low view in the Bible}

One example in the Bible that portrays a low view of childhood is the negative references to childhood as a phase of life in a metaphorical way in some New Testament epistles (cf. Aasgaard 2008). The logic behind using the metaphor is that (adult) believers are reprimanded for behaving childishly. With the childhood metaphor, adult believers are motivated not to be or become like children. The metaphor is thus referring to spiritual immaturity. The use of the metaphor in this way is found in three New Testament letters: 1 Corinthians, Ephesians and Hebrews (cf. Grobbelaar 2008:344-359). Although debatable, the letters using the childhood metaphor negatively were probably written by different authors at different historical periods, from and for different contexts. The implication is that it is possible that this metaphor was used widely, not only in the 1st-century Mediterranean world but also amongst the early Christians.

This childhood metaphor is a characteristic of Paul's first letter to the Corinthians (Aasgaard 2007:144). He used it three times in this letter. In this article, attention will be given only to how Paul used the metaphor of childhood as a phase of life in 1 Corinthians.

\section{A high view in the Bible}

A high view of childhood expressed in the Bible is the positive references to childhood by the authors of the Synoptic Gospels. Space constraints do not allow the investigation of all the texts in the Synoptic Gospels referring to children in this article. Therefore, the focus will only be on the childhood metaphors and other sayings expressing the same sentiment towards children in the gospels of Matthew, Mark and Luke. Although we should keep in mind that the Synoptic Gospels represent a narrative genre that differs from the letters of the New Testament, all the authors used the same metaphor to express a specific message. The authors of the Synoptic Gospels, however, apparently used child-related language directly in contrast to Paul. Whilst Paul called on believers to stop being like children, the Gospels urged adults to change and become like children.

\section{The childhood metaphor in 1 Corinthians}

Aasgaard (2007:128) opined that we could learn much of Paul's views of children from how he used his ideas about children and childhood to communicate a specific message in his letters. Paul used the childhood metaphor three times in 1 Corinthians. Paul's language and ideas about childhood are more complex and nuanced than his metaphorical use of childhood in 1 Corinthians (cf. Aasgaard 2008:249-277).

Therefore, the present discussion should not be regarded as a full representation of his child-related language. The goal of this research is to identify the place of children in Paul's thinking, as expressed in his use of the childhood metaphor in 1 Corinthians. To understand his use of this metaphor in 1 Corinthians, we have to consider the historical situation in Corinth, as well as the origin and use of the childhood metaphor in antiquity.

\section{The historical situation in Corinth}

Paul wrote 1 Corinthians possibly between AD 53 and 55, probably 3 years after he planted the church (cf. Ac 18). The city of Corinth was, a strategic trade centre, abundantly wealthy, described (Fee 2014:n.p) as 'an aristocracy of money'. Furthermore, it was 'an oligarchy that was hierarchic and elitist' (Um 2015:n.p.) and accommodated various religions (Fee 2014:n.p.).

Most of the church members had recently converted to Christianity (Ciampa \& Rosner 2010:n.p.). They were prone 
to the negative influences of the paganism and worldliness in their surrounding society and were 'inclined to throw in their lot with the values and culture of secular society' (Schreiner 2018:n.p.) to such an extent that the social values of the Corinthian society infiltrated the church (Ciampa \& Rosner 2010:n.p.) and characterised their behaviour.

The influences of the secular society came especially to the fore in the conflicts and compromises that characterised the Corinthian church. Blomberg (1994:Loc. 293-300) described them as 'wracked by division', and their 'disunity was marked by a recurring arrogance and immaturity' (Blomberg 1994:Loc. 241). According to Nash (2009:n.p.), the harmony of the body of Christ was fractured by a type of elitism. However, these rivalries were not only about sociological or ethical differences. They were 'fundamentally symptomatic of theological error' (Fitzmyer 2008:n.p.), which influenced the spiritual life of the church.

According to Witherington (1995:47), part of Paul's goal with his letter was probably to reconcile the different factions with each other. Therefore, he wrote in 1 Corinthians 1:10:

I appeal to you, brothers, by the name of our Lord Jesus Christ, that all of you agree, and that there be no divisions among you, but that you be united in the same mind and the same judgment.

This appeal forms the thesis of Paul's discourse, and the theme of unity features throughout the letter (Collins 1999:20; Hays 2011:21; Mitchell 1991:182; Witherington 1995:76). In Paul's message, the childhood metaphor plays an important role (cf. Aasgaard 2008:357). He used it three times in 1 Corinthians. To understand his way of using this metaphor, attention should be given to the historical use and development of this metaphor.

\section{Origin and use of the childhood metaphor in antiquity}

Childhood as a metaphor was well known in antiquity and widely used in Hellenistic rhetoric (Conzelman 1975:226). It seems as if Paul adopted this well-known metaphor for his admonishment of the Corinthian church. What is interesting regarding Paul's use of this metaphor is that he used words for children that emphasise age and not familial relations (Francis 1996:80). The Greek word he used in the first two instances, nēpios [baby or mere infant], literally means 'not speaking' (Bakke 2005:16; Francis 1996:70). It was usually associated with 'immaturity or being unlearned' (Francis 1996:67). Because children could not communicate through language as fluently as adults, it was generally accepted that they did not have the attribute of logos.

Therefore, they were seen as not capable of rational thinking and could not partake in the logical and intellectual world of adults (Bakke 2005:15-16; Francis 1996:70). According to Bakke (2005:16-21), Homer, Plato, Aristoteles, Cicero, Marcus Aurelius and Seneca wrote in this way about children.
Children were employed as symbols of irrational behavioral patterns and attitudes: one criticized other adults by calling 'their conduct "childish."' (Bakke 2005:54).

In using neppios in the first two metaphors, Paul echoed this Hellenistic view of children (Francis 1996:70-71). According to Fee (2014:n.p.), when Paul used nēpios, it 'almost always has a pejorative sense, in contrast with being adult, and refers to thinking or behavior that is not fitting for a "grownup"'. Although Paul used the word paidion in the last metaphor, Oepke's (1967:638) opinion is that it was often used figuratively, referring to 'undeveloped understanding'. It seems as if Paul used the concept 'child' in the same negative way as in the Hellenistic world to describe the relationship of the Corinthians with God.

\section{The different texts containing the childhood metaphor}

To understand Paul's use of the childhood metaphor, and thus his thinking about children as expressed in this metaphor, it is essential to look deeper into the three passages in which Paul used it.

\section{Corinthians 3:1-4:}

${ }^{1}$ But I, brothers, could not address you as spiritual people, but as people of the flesh, as infants in Christ. ${ }^{2}$ I fed you with milk, not solid food, for you were not ready for it. And even now you are not yet ready, ${ }^{3}$ for you are still of the flesh. For while there is jealousy and strife among you, are you not of the flesh and behaving only in a human way? ${ }^{4}$ For when one says, 'I follow Paul', and another, 'I follow Apollos', are you not being merely human? (English Standard Version [ESV])

Paul started his rebuke in 1 Corinthians 3:1-4 with a 'confrontational accusation' (Ciampa \& Rosner 2010:n.p), clearly pinpointing the Corinthians' lack of spiritual maturity. Because the believers have already received the spirit of God, their conduct should express God's wisdom. Instead, they are guided by earthly wisdom, 'which upholds the worldly values of superiority and competition, which result in factionalism' (Mitchell 1991:212). Therefore, Paul admonished them by addressing them as 'people of the flesh, as infants in Christ'. The terminology he used 'operates to draw strong contrasts between who they think they are, what their behavior says they are, and who they should be' (Nash 2009: n.p.).

Paul accused the Corinthians of failing to grow spiritually and being spiritually infants or babies, like 'little children crying over silly squabbles' (Mitchell 1991:213). This infantile behaviour shows that they do not understand what is truly important in the Christian life. Therefore, he must feed them with milk instead of solid food, as if they had not spiritually grown since the establishment of the church. Collins (1999:143; cf. 139) pointed out the overtones of irony: ' $[t]$ he Corinthians thought that they were very mature (2:6); in Paul's eyes, and from a Christian perspective, they were very childish'. Paul emphasised this irony by the metaphors he used. Hays (2011) stated: 
The metaphors used here (adults vs. infants and solid food vs. milk) are stock language in relation to philosophical and religious instruction throughout the ancient world. The assumption is that spiritual progress can be graded and that a different sort of curriculum is appropriate to each level of maturity. Thus, Paul is not coining fresh categories in order to classify the relative spiritual maturity of his readers; rather, he is turning the tables on the spirit-enthusiasts, placing them at the bottom of their own scale of religious achievement rather than at the top, where they suppose themselves to belong. They consider themselves mature and spiritual, but Paul replies with a putdown: sorry, you remain immature and fleshly. (p. 48)

Aasgaard (2008:261) explained, '[ $h]$ ere, infancy is employed to indicate religious inadequacy: the Corinthians have fallen to a stage below what is required'. Using the metaphor in this negative way, Paul wanted to wake them up to live like people who had received and were guided by the Spirit of God.

\section{Corinthians 13:11:}

When I was a child, I spoke like a child, I thought like a child, I reasoned like a child. When I became a man, I gave up childish ways.

With 1 Corinthians 13, Paul wanted to encourage the Corinthian church to use all their gifts in a certain way: with love towards each other. He did not consider love as an emotion or an attitude, but as the way or sine qua non of the Christian life (Collins 1999:471). Love was the only antidote or cure for the factionalism amongst them (Mitchell 1991:271) because it 'promotes concord and combats against factions' (Oropeza 2017:n.p.).

Furthermore, 1 Corinthians 13 contains three distinctive parts (Blomberg 1994:226; Fitzmyer 2008:n.p.; Hays 2011:221; Witherington 1995:267). Collins (1999) explained the structure as follows:

Verses 1-3 affirm that without love charismatic gifts have no real value. Verses 4-7 offer a panorama on love, featuring both its positive and negative qualities, that is, what love does and what love does not do. Verses 8-13 contrast love with the spiritual gifts, affirming that love never ends. (p. 472)

In verses 8-13, Paul stressed again what will be beneficial for the church, only from another perspective: the eschatology (Mitchell 1991:278). From this eschatological perspective, he indicated that there are gifts that will end, but love will endure. The verb katargein, often used in the context of eschatological discourses (Schreiner 2018:n.p.), is a word Paul used regularly. Hays (2011) explained:

[I]t consistently refers to God's nullification and abolition of everything that is ephemeral or - in some case - opposed to him ... In verse 8 , to be sure, the gifts listed are not allied with powers hostile to God; rather, they will be abolished simply because they will no longer be necessary when the Lord returns and the fullness of his kingdom is present. (p. 229)

Connecting with the ceasing of these gifts, Paul emphasised that believers know and prophesy only in part, 'but when the perfect comes, the partial will pass away' (1 Cor 13:10). In this regard, Wright (2003) stated:

The point of 13:8-13 is that the church must be working in the present on the things that will last into God's future. Faith, hope and love will do this; prophecy, tongues and knowledge, so highly prized in Corinth, will not. They are merely signposts to the future; when you arrive, you no longer need signposts. Love, however, is not just a signpost. It is a foretaste of the ultimate reality. (p. 296)

It is in this context that Paul used the metaphor of the child in verse 11 as an illustration to explain the difference between 'partial' and 'perfect'. It seems as if 'spoke, thought and reasoned like a child' refers to what is partial and not perfect. It is this partial phase to which the gifts of speaking in tongues and prophesy and knowledge belong, and which, like the years of childhood, will end and culminate in what is perfect (Schreiner 2018):

Paul does not demean these gifts in comparing them to childhood, but he does put a temporal limit on them. Just as the days of childhood are temporary, so are the gifts God has given the church. (n.p.)

With this metaphor, Paul was relativising the value of the gifts and warning the Corinthians to be careful not to regard the gifts too highly. Although they have a role to play in the present, their usefulness will pass away. The gifts are not the ultimate good in life.

\section{Corinthians 14:20:}

Brothers, do not be children in your thinking. Be infants in evil, but in your thinking be mature.

In 1 Corinthians 14, Paul moved back to the theme of spiritual gifts, which he discussed in 1 Corinthians 12 . In this section, he did not discuss all the spiritual gifts but focused only on speaking in tongues and prophesies. In evaluating these two gifts, Paul's primary interest was whether it served the upbuilding of the Corinthian church (Collins 1999:505). He expressed his concern about the dividing influence speaking in tongues in their public meetings had on the church. To address this problem, Paul indicated that those who want to speak in tongues should pray that they will be able to interpret it (1 Cor 14:13). Otherwise, no outsider could understand their 'tongues-language' and respond with 'amen' (1 Cor 14:16). The consequence was that they would not be edified.

In the next section, 1 Corinthians 14:20-25, Paul moved away from stressing the importance of prophecy for the upbuilding of the church to the possible influence speaking in tongues and prophecy could have on outsiders and unbelievers (Hays 2011:238; Collins 1999:505). Paul started his argumentation in verse 20 with a firm rebuke. In the process, he used the metaphor of a child twice. In the first place, he warned them not to be children in their thinking, but rather mature. Taking the rest of 1 Corinthians 14 into consideration, it seems as if Paul's point with this metaphor was that the Corinthians in their ecstatic use of the gift of speaking in tongues muttered as if they were babies, who did not express themselves clearly and understandably. 
His main problem with speaking in tongues was the incomprehensible nature of it (Nash 2019:n.p.), especially for the unbelievers, who could not understand what God was saying to them. Thus, they could not respond in a positive way. Paul advised them that if they spoke in tongues, they should instead act like rational adults. As sort of an afterthought, he added, ' $b]$ e infants in evil, but in your thinking be mature'.

In 1 Corinthians 14:23, Paul explained his view further by adding:

If, therefore, the whole church comes together and all speak in tongues, and outsiders or unbelievers enter, will they not say that you are out of your minds?

Paul used the Greek word mainesthe only once (Collins 1999:509). Fitzmyer (2008:n.p.) indicated that it is a powerful word that literally means 'you are $\mathrm{crazy}^{\prime}$, sometimes indicating in antiquity that a person was demon possessed. According to Collins (1999:509), 'it was often used in reference to cultic frenzy'. It was also possible that ' $[t]$ he typical pagan Corinthian ... would say, "Oh, this is just another group like the devotees of Dionysius or Cybele" - one more consumer option in a pluralistic religious market' (Hays 2011:238-239). The Corinthians' childish gibberish prevented the nonbelievers from hearing and receiving the Gospel and only strengthened their disbelief (Nash 2009:n.p.). However, with the gift of prophecy, it was different. The believers understood it, they were built up in their faith, and it could 'have a powerful effect on nonbelievers because it is both supernatural and intelligible' (Witherington 1995:285).

It is in the context of this argumentation that Paul used the metaphor of a child in verse 20. It seems as if Paul believed the use of the gift of speaking in tongues in the church's public meeting was to act like a child. It was a sign of immaturity, thinking only of one's own religious experiences without considering the effects it might have on believers and unbelievers. This accusation is similar to the one he made in 1 Corinthians 3:1-4 in connection with the divisions amongst the Corinthians. Paul used childhood in 1 Corinthians 14:20 as a negative metaphor to achieve a definite goal. He tried to convince the Corinthian church to become more mature and to act like adults in their meetings. Paul's plea was essentially the following: do not act like children. Do not be children. Grow up spiritually and act like adults.

\section{Some summarising remarks}

What was the place of children in Paul's thinking as expressed in 1 Corinthians? In light of the above discussion, some preliminary remarks are made.

The different texts in 1 Corinthians show that Paul used the childhood metaphor to address some aspects of an adult's relationship with God. It is part of his rhetorical strategy to motivate and convince the Corinthians that they must change their behaviour and become spiritually more mature. Paul used childhood metaphor to express for the Corinthians what they should not be in their relationship with God. It seems as if Paul associated children with childishness. According to Thatcher (2007), Paul's use of this metaphor in 1 Corinthians probably:

$[A]$ ssumes that being a child is an unenviable, provisional, and ignorant state to be left behind quickly and gladly. When the child/adult distinction is made into an analogy by being compared with the natural/spiritual distinction, the dismissive attitude to children becomes clearer. (p. 145)

How Paul used the childhood metaphor illustrates that he had a low view of childhood (cf. Berryman 2009 and the discussion above). Paul's attitude towards children in 1 Corinthians can be described as disrespectful, indifferent and even unconcerned. He did not see children as subjects from whom adults can learn spiritually, but rather as objects whom adults should teach. For him, adulthood was the norm for spiritual maturity, and children could only be spiritually mature when they become adults.

In this context, Paul was a child of his time, as evident from his view of children informed by his surrounding culture (cf. Aasgaard 2008:272 \& 277), depending 'on common mentality and on philosophical and literary topoi concerning children' (Aasgaard 2008:272). It seems as if Paul 'sees children from the perspective of ancient patriarchy' (Aasgaard 2008:272). The fact that Paul used the childhood metaphor as a strategy to persuade and motivate the Corinthians to change their lives and to grow to the ideal Paul envisioned creates the impression that the Christian Corinthians' view of children confirmed the opinions of the society in which they lived. Therefore, DeVries (2001) was probably correct in stating that the early church, of which the Corinthians were a part, viewed children as:

$[W]$ eaker, subordinate members of the community of faith, whose physical, emotional, and spiritual immaturity render them [as] objects of adult discipline but not bearers of spiritual insight or models of faith. (p. 167)

It is understandable that Paul, to be rhetorically persuasive, linked his arguments to this general and widely accepted notion of childhood in the world of his addressees (Aasgaard 2008:372).

Nevertheless, reading, interpreting and applying these texts from a childist approach in the context of the 21st century is difficult. Not only do they express a negative, dismissive view towards children, but they also contradict the general and growing cultural understanding of children as agents of their own lives and participators in the adult world. They also create a negative view of the spiritual life and maturity of children in a time that emphasises children's unique spiritual or religious potential and capabilities.

Against this background, it is more and more accepted in Christian and religious education, as well as spiritual development, that adults and children need each other to grow spiritually. Westerhoff (2008:365) said '[c]hildren are God's gift to aid us [adults] to mature spiritually'. To be aided in their spiritual growth, adults have to listen carefully to children. Stonehouse and May (2010) stated: 
When working with very young children. I (Scottie) have found that listening often has to take a different form - that of watching children. Children three, four, and five years of age often do not have the language to speak adequately about their perception of God, but through careful observation it is evident that they can be deeply spiritual. (p. 23)

Bunge (2012) also emphasised that adults have the responsibility not only to listen to children but also to learn from them. She declared (Bunge 2012):

The Bible, the Christian tradition, and common experience reveal that children are not just students of adults. They can also be moral witnesses, models of faith for adults, sources or vehicles of revelation and inspiration, and representatives of Jesus. They can nurture, deepen, and challenge the faith of adults. (p. 11)

These new views about childhood, with other theological arguments, have led to a growing emphasis on intergenerational faith formation (cf. Allen \& Ross 2012; ed. Allen 2018; Amidel, Merhaut \& Roberto 2014; Grobbelaar 2008). This approach intends to create opportunities for interaction and learning between children and older generations and to establish an intergenerational culture in a congregation. However, it is almost impossible to achieve this goal if adults view children according to Paul's low view of children, as expressed in his use of the childhood metaphor in 1 Corinthians. This low view of childhood leads inevitably to the 'adultisation' of faith (cf. Thatcher 2010:140). Confronted with this problem, we should consider other biblical texts about children. In this regard, some scholars think that we have to consider how the authors of the Synoptic Gospels viewed children and used the childhood metaphor (cf. Berryman 2009:14-19; Grobbelaar 2016c; Jensen 2005:124-134; Thatcher 2010; White 2011; Willmer \& White 2013).

\section{Childhood in the Synoptic Gospels}

The theology of childhood expressed in the use of the childhood metaphor by the authors of the Synoptic Gospels differs radically from Paul's theology of childhood, expressed in his use of the childhood metaphor in 1 Corinthians. They stated their high view of children in the following texts:

At that time the disciples came to Jesus, saying, 'Who is the greatest in the kingdom of heaven?' ${ }^{2}$ And calling to him a child, he put him in the midst of them ${ }^{3}$ and said, 'Truly, I say to you, unless you turn and become like children, you will never enter the kingdom of heaven. ${ }^{4}$ Whoever humbles himself like this child is the greatest in the kingdom of heaven. ${ }^{5}$ Whoever receives one such child in my name receives me'. (Mt 18:1-5)

${ }^{33}$ And they came to Capernaum. And when he was in the house he asked them, 'What were you discussing on the way?' ${ }^{34}$ But they kept silent, for on the way they had argued with one another about who was the greatest. ${ }^{35}$ And he sat down and called the twelve. And he said to them, 'If anyone would be first, he must be last of all and servant of all' ${ }^{36}$ And he took a child and put him in the midst of them, and taking him in his arms, he said to them, ${ }^{37}$ Whoever receives one such child in my name receives me, and whoever receives me, receives not me but him who sent me'. (Mk 9:33-37)

An argument arose among them as to which of them was the greatest. ${ }^{47}$ But Jesus, knowing the reasoning of their hearts, took a child and put him by his side ${ }^{48}$ and said to them, 'Whoever receives this child in my name receives me, and whoever receives me receives him who sent me. For he who is least among you all is the one who is great'. ( $\operatorname{Lk~9:46-48)~}$

The Synoptic Gospels attribute these sayings to Jesus. Although it is not certain that they originated from the historical Jesus, these sayings were of such importance that they were preserved in the oral tradition(s) of the early church and became part of the written Synoptic Gospels. Referring to these texts, the reference is not to the historical Jesus but to the Jesus of the gospels and accordingly to the theology of the specific author of the particular gospel.

In the preceding texts, there are similarities as well as some differences. It could be that 'this kind of talk and parabolic action happened more than once, or perhaps these are different memories of the same event' (Berryman 2009:16). What is similar is that Jesus taught his disciples about greatness in God's kingdom by using a child, thereby explaining to them the actual values of God's kingdom. Jesus indicated by his actions and words that children can enter God's kingdom and that they also reveal God (Berryman 2009:16). Even if these narratives cannot be traced back in their totality to the historical Jesus, the central truth of these narratives became so crucial in the Jesus tradition that each of the authors of the Synoptic Gospels included it in their Jesus story. If this view did not originate from the historical Jesus, the truth it expresses was so important that it became part of the theology of each one of the authors of the Synoptic Gospels, proclaiming that it was part of Jesus' implied view of childhood.

\section{Change and become like children}

Jesus' actions here are absolutely countercultural. There do not exist any 'Jewish texts in which children are examples or models to be imitated' (Davies \& Allison 2004: n.p.). Furthermore, where '[a]ncient moralists regularly trotted forth models of heroes and statesmen for their students to imitate; Jesus instead points to a child' (Keener 2009: n.p.), the least important person in their society. In using a child, Jesus turned the usual views of childhood, the relationship between children and adults, and the roles they play in the surrounding context, upside down (Berryman 2009:15). He contradicted the traditional views about childhood in the 1st-century Mediterranean world (cf. Grobbelaar 2016c:132-186), because in this context '[c]hildren had no social clout or independent rights' (Chouinard 1997; Mt 18:2).

The change Jesus expected from his disciples was not to acquire a specific characteristic of children like 'innocence or simplicity or sinlessness' or self-conscious humbleness, but rather to identify themselves with the humble status or position of children in the surrounding society (Davies \& Allison 2004: n.p.). The disciples should become and live like someone without any status, a nobody, weak and vulnerable, just like the children around them. 
In a certain sense, Jesus' pronouncement was shocking for his hearers. To enter God's kingdom, to be a real leader in Jesus' community, the disciples must grow backwards, must become like children, people without any status in their surrounding world. To become 'great', spiritually mature, you have to deny yourself, take up your cross and die (Mt 16:24-28), you have to become a servant, a slave (Mt 20:20-28) and, as expressed in Matthew 18:1-4, you have to change and become like children (cf. Grobbelaar 2008:313-315).

This change to become like children before entering God's kingdom also comes to the fore in both the Gospel of Mark (10:15) and the Gospel of Luke (18:17). Expressed in other words than in Matthew, both Mark and Luke declare that whoever does not receive the kingdom of God as a little child will never enter it. In this regard, Berryman (2009) asserted that:

[T] he child, whose value as a spiritual teacher is high, teaches the low adult, who is older and is assumed more important, how to enter the kingdom. The irony is that the adult may stay low and unable to touch the kingdom because of an inflated selfevaluation as being higher than children in importance and unable to learn from them. (p. 19)

The way Jesus used the childhood metaphor for entering into and becoming part of God's kingdom is directly opposite to the way Paul used it in 1 Corinthians. Paul used the childhood metaphor as an indication of the spiritual immaturity of the Corinthians: adults, you should not be like children. According to the Synoptic Gospels, not to strive for importance, not to think you are more important than any member of your faith family, not to boast about your gifts, and not to enhance strife and division in the church, as in the case of the Corinthians, is to become a child without any power. It is to become less, small, without status, like a child in the 1st-century Mediterranean world. The Synoptic Gospels say to adults, 'become like children'. This expression presents a high view of childhood. It is a view that stresses the vital role of children's agency in changing adults into mature followers of Christ. Adults need children in their lives, and therefore Jesus gave the disciples the instruction to receive the children in their lives.

\section{Receive a child in Jesus' name}

The emphasis placed in all three narratives mentioned above on the importance of receiving a child illustrates the same high view of childhood. According to Osborne (2010:Loc. 12584), receiving 'involves welcome, loving reception, and acceptance'. Hagner (1995:522; cf. Malina \& Rohrbaugh 2003:92) interpreted 'receiving' as being hospitable towards children. All these interpretations have one common theme: the adult disciples should serve the children. They should do it unusually: they have to welcome the children in Jesus' name. In following Jesus in this world, the disciples become representatives of Jesus, and therefore they should emulate Jesus' behaviour by welcoming the children into their lives.
What is more extraordinary in Jesus' statement is that he added that those who receive a little child in his name also receive him. Both Mark and Luke added that they also received the One who sent Jesus. The implication is that Jesus identified himself with children. Children become the embodiment of Jesus in adults' lives. Those who show hospitality to a child will experience in the child that they are welcoming not only Jesus' presence but also the presence of the God who sent him.

By stating that the disciples should become like a child and see children as the embodiment of Jesus, the authors of the Synoptic Gospels reflected a high view of childhood. They did not describe children as symbols of spiritual immaturity but rather as people representing and revealing God.

\section{'Not to be a child' or 'to become a child'?}

The metaphor of childhood is used in totally different ways by the apostle Paul and the authors of the Synoptic Gospels. Paul used it as an expression of spiritual immaturity, of what the adults in the Corinthian church should not be. In the Synoptic Gospels, Jesus used it as an expression of what his disciples should become. Behind these different ways of using the same metaphor lie different views of childhood. Paul viewed children as spiritually immature, and therefore adults should not become like them. For the authors of Synoptic Gospels, childhood is a symbol of spiritual maturity. The Jesus of the Synoptic Gospels and Paul each use the childhood metaphor differently, but both can be true. The problem is that Paul's use of the childhood metaphor expresses a negative view of children and childhood.

By using children as a metaphor of immaturity, Paul contributed to the enhancement of the prevailing negative image of childhood in the surrounding Mediterranean world and amongst the church in Corinth.

By contrast, the use of the childhood metaphor by the Jesus of the Synoptic Gospels expresses a positive view of childhood. This view challenges the negative image of childhood in the surrounding Mediterranean world. It enhances a radically new and positive way of seeing children. This radical new view is supported by Francis' (1996:81) observation that according to the authors of the Synoptic Gospels Jesus did not use the childhood metaphor in a way that belittled children.

In this regard, the following observation by Strange (2004) seems true:

Jesus invited his followers to look at children with new eyes. The writers of the New Testament letters [in this case Paul] used the image of the child in their description of discipleship in much more conventional ways. For them [Paul], children were persons under the authority of parents, ready examples of immaturity and of potential for growth. All of these are quite legitimate ways of viewing children, but each one corresponds to the accepted perception of the children in society, rather than, as with Jesus, challenging that perception. (p. 69) 
All adult theologians today are confronted with both these views of childhood: not to be a child or to become a child. It will be difficult, if not impossible, to do theology with children as our equal partners if we operate with a low view of childhood, as expressed in the childhood metaphor in 1 Corinthians - or in any of the three ways, or any combination thereof, identified by Berryman (2009). A childist reading of the Bible can only be practised with a high view of childhood, as expressed in the childhood metaphor used in the Synoptic Gospels.

Usually we think that we have to care for and educate children because we see them as immature and in need of adult guidance. As true as that may be, can we be converted from viewing children and childhood only as expressed by Paul in 1 Corinthians to the way in which children and childhood are viewed in the Synoptic Gospels? This is the place where all adult theologians must start when they embark on the way of doing theology with children as our equal partners and cotheologians. We shall have to overcome our inclination towards teaching and educating children, allowing children to be bearers of revelation and God's presence in our midst, and guiding us in entering God's kingdom (Berryman 2009:17-18):

Perhaps most important at this stage in our understanding ... can we be as willing to let what we learn from children change our theology and theory as we are willing to change children by the imposition of our theology and theory on them? (Hart 2006:175)

\section{Acknowledgements Competing interests}

The author declares that no financial or personal relationships exist which may have inappropriately influenced the writing of this article.

\section{Author's contributions}

I declare that I am the sole author of this research article.

\section{Ethical consideration}

This was a research project using human subjects in a lowrisk informal survey. The participants were informed of the purpose of the research and participated voluntarily and anonymously.

\section{Funding information}

This research received no specific grant from any funding agency in the public, commercial or not-for-profit sectors.

\section{Data availability statement}

Data sharing is not applicable to this article as no new data were created or analysed in this study.

\section{Disclaimer}

The views and opinions expressed in this article are those of the author and do not necessarily reflect the official policy or position of any affiliated agency of the author.

\section{References}

Aasgaard, R., 2007, 'Paul as a child: Children and childhood in the letters of the Apostle', Journal of Biblical Literature 126(1), 129-159. https://doi.org/10.2307/ 27638423

Aasgaard, R., 2008, 'Like a child: Paul's rhetorical uses of childhood', in M.J. Bunge, T.E. Fretheim \& B.R. Gaventa (eds.), The child in the Bible, pp. 249-277, William B. Eerdmans Publishing, Grand Rapids, MI.

Allen, H.C. (ed.), 2018, InterGenerate: Transforming churches through intergenerational ministry, Abilene Christian University Press, Abilene, TX.

Allen, H.C. \& Ross, C.L., 2012, Intergenerational Christian formation: Bringing the whole church together in ministry, community and worship, Kindle edn., IVP Academic, Downers Grove, IL.

Amidel, K., Merhaut, J. \& Roberto, J., 2014, Generations together. Caring, praying, learning, celebrating, and serving faithfully, LifelongFaith Associates, Naugatuck, CT.

Bakke, O.M., 2005, When children become people. The birth of childhood in early Christianity, transl. B. McNeil, Fortress Press, Minneapolis, MN.

Berryman, J.W., 2009, Children and the theologians. Clearing the way for grace, Morehouse Publishing, New York, NY

Betsworth, S. \& Parker, J.F. (eds.), 2019, T \& T Clark handbook of children in the Bible and the Biblical World, T \& T Clark, London.

Blomberg, C.L., 1994, 1 Corinthians, The NIV Application Commentary, Kindle edn., Zondervan, Grand Rapids, MI.

Bunge, M.J. (ed.), 2001, The child in Christian thought, William B. Eerdmans Publishing, Grand Rapids, MI.

Bunge, M.J., 2004, 'Historical perspectives on children in the church: Resources for spiritual formation and a theology of childhood today', in D. Ratcliff (ed.), Children's spirituality: Christian perspectives, research and applications, pp. 42-53, Cascade Books, Eugene, OR.

Bunge, M.J., 2006, 'The child, religion and the academy. Developing robust theological and religious understandings of children and childhood', Journal of Religion 86(4), 549-579. https://doi.org/10.1086/505894

Bunge, M.J., 2012, 'Biblical and theological perspectives and best practices for faith formation', in K.E. Lawson (ed.), Understanding children's spirituality: Theology, research, and practice, Kindle edn., pp. 4-25, Cascade Books, Eugene, OR.

Bunge, M.J., 2016, 'Task, sources and significance of theologies of childhood', in J. Grobbelaar \& G. Breed (eds.), Theologies of childhood and the children of Africa, pp. 92-112, AOSIS, Durbanville.

Bunge, M.J., Fretheim, T.E. \& Gaventa, B.R. (eds.), 2008, The child in the Bible, William B. Eerdmans Publishing, Grand Rapids, MI.

Chouinard, L., 1997, Matthew, Logos edn., College Press, Joplin, MO.

Ciampa, R.E. \& Rosner, B.S., 2010, The first letter to the Corinthians, The Pillar New Testament commentary, William B. Eerdmans Publishing, Grand Rapids, MI.

Collins, R.F., 1999, First Corinthians, Sacra Pagina series, Davies \& Allison Add Logos edn., The Liturgical Press, Collegeville, MN.

Davies, W.D. \& Allison, D.C. Jr., 2004., A critical and exegetical commentary on the gospel according to Saint Matthew, vol. 2, T\&T Clark International, New York, NY.

DeVries, D., 2001, 'Toward a theology of childhood', Interpretation 55(1), 161-173. https://doi.org/10.1177/002096430005600205

Elkins, K.G. \& Parker, J.F., 2016, 'Children in biblical narrative and childist interpretation', in D.N. Fewell (ed.), The Oxford handbook of biblical narrative, pp. 422-433, Oxford University Press, New York, NY.

Fee, G.D., 2014, The first epistle to the Corinthians, The New International Commentary on the New Testament, rev. edn., Logos edn., William B. Eerdmans Publishing, Grand Rapids, MI.

Fitzmyer, J.A., 2008, First Corinthians: A new translation with introduction and commentary, The Anchor Yale Bible, Logos edn., Yale University Press, New Haven, $\mathrm{CT}$.

Francis, J., 1996, 'Children and childhood in the New Testament', in S.C. Barton (ed.), The family in theological perspective, pp. 65-85, T \& T Clark, Edinburgh.

Garroway, K.H., 2018, Growing up in ancient Israel: Children in material culture and biblical texts, SLB Press, Atlanta, GA.

Grobbelaar, J., 2008, 'Die bediening aan laerskoolkinders in en deur die gemeente as 'n intergenerasionele ruimte', unpublished DTh dissertation, Dept. of Practical Theology and Missiology, University of Stellenbosch, Stellenbosch.

Grobbelaar, J., 2016a, 'Resources on theology and children', in J. Grobbelaar \& G. Breed (eds.), Theologies of childhood and the children of Africa, pp. 1-50, AOSIS, Durbanville. 
Grobbelaar, J., 2016b, 'The grammar of combining the vocabulary of theology, children and Africa', in J. Grobbelaar \& G. Breed (eds.), Theologies of childhood and the children of Africa, pp. 51-91, AOSIS, Durbanville.

Grobbelaar, J., 2016c, 'Jesus and the children in the Gospel of Matthew', in J. Grobbelaar \& G. Breed (eds.), Theologies of childhood and the children of Africa, pp. 132-186, AOSIS, Durbanville.

Hagner, D.A., 1995, Matthew 14-28, Word Books, Dallas, TX.

Hart, T., 2006, 'Spiritual experiences and capacities of children and youth', in E.C. Roehlkepartain, P.E. King, L. Wagner \& P.L. Benson (eds.), The handbook of spiritual development in childhood and adolescence, pp. 163-177, Sage, Thousand Oaks, CA.

Hays, R.B., 2011, First Corinthians, interpretation: A Bible commentary for teaching and preaching, Kindle edn., Westminster John Knox Press, Louisville, KY.

James, A. \& James, A., 2012, Key concepts in childhood studies, SAGE Key Concepts series, Kindle edn., Sage, London.

Jensen, D.H., 2005, Grace vulnerability: A theology of childhood, The Pilgrim Press, Cleveland, $\mathrm{OH}$.

Keener, C.S., 2009, The Gospel of Matthew: A socio-rhetorical commentary, Logos edn., William B. Eerdmans Publishing, Grand Rapids, MI.

Koepf Taylor, L.W., 2013, Give me children or I shall die: Children and communa survival in biblical literature, Kindle edn., Fortress Press, Minneapolis, MN.

Malina, B.J. \& Rohrbaugh, R.L., 2003, Social sciences commentary on the Synoptic Gospels, 2nd edn., Fortress Press, Minneapolis, MN.

Mercer, J.A., 2005, Welcoming children. A practical theology of childhood, Chalice Press, St. Louis, MO.

Miller-McLemore, B.J., 2003, Let the children come: Reimagining childhood from a Christian perspective, Jossey-Bass, San Francisco, CA.

Mitchell, M.M., 1991, Paul and the rhetoric of reconciliation: An exegetical investigation of the language and composition of 1 Corinthians, JCB Mohr, Tübingen.

Nash, R.S., 2009, 1 Corinthians, Logos edn., Smyth \& Helwys Publishing, Macon, GA

Nye, R., 2009, Spirituality. What it is and why it matters, Kindle edn., Church House Publishing, London.

Oepke, A., 1967, 'rais', in G. Friedrick (ed.), Theological dictionary of the New Testament, vol. 5, pp. 636-654, transl. G.W. Bromiley, William B. Eerdmans Publishing, Grand Rapids, MI.
Oropeza, B.J., 2017, 1 Corinthians: A new Covenant commentary, New Covenant Commentary Series, Logos edn., Cascade Books, Eugene, OR.

Osborne, G.R., 2010, Matthew, Zondervan Exegetical Commentary on the New Testament Book 1, Kindle edn., Zondervan, Grand Rapids, MI.

Parker, J.F., 2019, 'Children in the Hebrew Bible and childist interpretation', Currents in Biblical Research 17(2), 130-157. https://doi.org/10.1177/1476993X 18821324

Schreiner, T.R., 2018, 1 Corinthians: An introduction and commentary, Tyndale New Testament Commentaries, Olive Tree edn., InterVarsity Press, Downers Grove, IL.

Stonehouse, C. \& May, S., 2010, Listening to children on the spiritual journey, Baker Academic, Grand Rapids, MI.

Strange, W.A., 2004, Children in the early church. Children in the ancient world, the New Testament and the early church, reprinted, Wipf \& Stock Publishers, Eugene, OR.

Thatcher, A., 2007, Theology and families, Blackwell Publishing, Oxford.

Thatcher, A., 2010, 'Beginning again with Jesus', in A. Dillen \& D. Pollefeyt (eds.), Children's voices: Children's perspectives in ethics, theology and religious education, pp. 140-161, Uitgeverij Peeters, Leuven.

Um, S.T., 2015, 1 Corinthians, Preaching the Word, Olive Tree edn., Crossway, Wheaton, IL.

Westerhoff, III, J.H., 2008, 'The church's contemporary challenge: Assisting adults to mature spiritually with their children', in H.C. Allen (ed.), Nurturing children's spirituality: Christian perspectives and best practices, pp. 355-365, Cascade Books, Eugene, OR.

White, K.J., 2011, 'Children as signs of the kingdom of God - A challenge to us all. Matthew 18:1-14', in S. Arles, D. Brewster, C. Kok, R. Tan \& K.J. White (eds.), Now and next: A compendium of papers presented at the Now \& Next theological conference on children at Nairobi, Kenya, Compassion International, March 9-12, 2011, pp. 41-61.

Willmer, H. \& White, K.J., 2013, Entry point: Towards child theology with Matthew 18 WTL Publications, London.

Witherington, B. III, 1995, Conflict and community in Corinth. A socio-rhetorical commentary on 1 and 2 Corinthians, William B. Eerdmans Publishing, Grand Rapids, MI.

Wright, N.T., 2003, The resurrection of the Son of God, Society for Promoting Christian Knowledge, London. 